DOI 10.4467/2543733XSSB.19.002.11401

RYSZARD FILAS

Uniwersytet Jagielloński

\title{
POCZĄTKI BADAŃ PRASOZNAWCZYCH POD ZABORAMI I W POLSCE ODRODZONEJ: TROPY GALICYJSKIE I KRAKOWSKIE
}

\author{
The Beginnings of Press Studies During the Partitions and in the Reborn Poland: \\ Galician and Krakow tropes
}

Summary

The article is of a review nature. It deals with the beginnings of press studies and the gradual crystallization of press studies as a scientific discipline in Poland, conducted or published mainly, though not exclusively in the areas of Galicia and Małopolska.

The author recalls - behind the works of Sylwester Dziki - pioneering research conducted in the Lviv and Krakow centers in the nineteenth century by several generations of professional bibliographers and historians (such as J.S. Bandtkie, K.J.T. Estreicher) and amateur enthusiasts (such as A. Chłędowski, K. Szajnocha, S.J.N. Czarnowski). At the beginning of the twentieth century, they took the form of broader organizational activities (S. Gorski, S.T. Jarkowski), in particular related to the implementation of the ideas adopted at the Krakow Congress of Journalists (1911) and implemented gradually after regaining independence, mainly by Jarkowski and his colleagues. The article shows the process of the institutionalization of Polish press studies in the dimension of journalistic education (especially at the academic level), the development of journalism integrating press researchers, and finally - a long-term fight for the establishment of a center researching the press.

These three ideas materialized partly in the interwar period through the activities of, among others, the Academy of Journalism in Warsaw (1927-1939). However, they developed in a more mature form only after the Second World War, with the establishment of the Polish Institute of Social Sciences and the "Press Poland" industry monthly. In the following years, journalism studies at the University of Warsaw and Jagiellonian University as well as scientific journals like "the Press Studies Quarterly" (the body of the Press Research Institute in Warsaw) and "the Contemporary and Early Press" (related to the Press Research Centre in Krakow) were established.

Keywords: press studies in the Polish lands, precursors to press studies, Galicja, Stanisław Jarkowski, institutionalization, press journals, journalist training, press research center 
Słowa kluczowe: prasoznawstwo na ziemiach polskich, prekursorzy badań nad prasą, Galicja, Stanisław Jarkowski, instytucjonalizacja, periodyki prasoznawcze, kształcenie dziennikarzy, ośrodek badań nad prasą

\section{O prasoznawstwie i badaniach nad prasą}

Prasoznawstwo (zastąpione modniejszym dziś terminem „medioznawstwo”) nie jest, jak wiadomo, nauką starą. Dość trudno ustalić, kiedy powstało, bo oczywiście nie da się przypisać konkretnej daty czemuś, co jest wieloletnim procesem. I ma wyraźne podwójne korzenie, z jednej strony - akademickie, ale z drugiej - związane z praktyką prasowo-wydawniczą i próbami refleksji teoretycznej i badań nad jej różnymi aspektami, podejmowanymi w gronie praktyków - dziennikarzy, wydawców czy niekiedy po prostu pasjonatów - hobbistów.

Jeśli zastosować kryteria akademickie, to w Europie ogniwa tego łańcucha rozciagały się przez ponad stulecie - od pierwszego cyklu wykładów na temat założeń teoretycznych nauki o prasie (Zeitungswissenschaft), wygłoszonego na Uniwersytecie Wrocławskim już w roku 1806, poprzez późniejszą działalność Karla Büchera (od 1884 roku na Uniwersytecie w Bazylei, potem w Lipsku), utworzenie pierwszej katedry dziennikarstwa na Uniwersytecie w Zurychu (1903) oraz pierwszego w Europie instytutu prasoznawczego (Institut für Zeitungskunde) w Lipsku (1916), aż do symbolicznego nadania w 1924 roku pierwszego tytułu profesora prasoznawstwa Karlowi d'Esterowi (który uzyskał doktorat na Uniwersytecie w Münster za teoretyczną pracę na temat prasy) ${ }^{1}$. W Ameryce szkolnictwo dziennikarskie wyłoniło się wcześniej, choć też stopniowo, poczynając od utworzenia sekcji dziennikarskiej w Washington College w Lexington (1869), później na Uniwersytecie Columbia (Missouri, 1884)2 , na Uniwersytecie Pensylwania (1893-1894), z kolei w latach 1910-1920 powstały dziennikarskie sekcje, szkoły i wydziały z prawami szkół wyższych na wielu innych uniwersytetach, w tym na słynnym Columbia University $(\mathrm{NY})^{3}$. Pisząc o tym akademickim podłożu kształtowania się prasoznawstwa jako nowej dyscypliny naukowej, Mieczysław Kafel podkreśla wyraźną różnicę między uczelniami europejskimi a amerykańskimi:

Przedmiotem badań szkoły niemieckiej (a nawet ogólnie - europejskiej) były przede wszystkim: historia myśli społecznej w prasie, socjologia prasy (jako część socjologii ogólnej), problemy prawne, literackie, a także (szkoła francuska) psychologiczne. Są to badania na pewno bardzo pożyteczne dla kultury danego kraju, ale (...) mogą i powinny być prowadzone w ramach dyscyplin tradycyjnych, jak prawo, socjologia, historia, psychologia itp. Europejskie szkoły dziennikarskie powstałe na początku XX wieku dawały studentom wiedzę o socjologii i sytuacji prawnej prasy, nie zaś znajomość problemów praktyki prasowej ${ }^{4}$.

\footnotetext{
${ }^{1}$ Wszystkie fakty przytaczam za: M. Kafel, Prasoznawstwo, Warszawa 1966, s. 29-33.

${ }^{2}$ Już w 1878 r. powstała tam pierwsza uniwersytecka katedra historii prasy. Zob. M. Kafel, op. cit., s. 36.

${ }^{3}$ Ibidem, s. 36-37.

${ }^{4}$ Ibidem, s. 33. Pewną zmianę podejścia znajdujemy dopiero w książce Emila Löbla (1863-1942), uchodzącą za pierwszy europejski podręcznik dziennikarstwa. Zob. E. Löbl, Kultur und Press, Wiedeń 1903, przekład polski i przedmowa S. Gorskiego: Kultura i prasa, Warszawa 1905.
} 
Natomiast programy szkół amerykańskich „(...) mają wyraźną tendencję wysuwania na pierwszy plan techniki pracy dziennikarskiej"5.

Na gruncie amerykańskim powstała też inna od europejskich koncepcja badań prasoznawczych. W przeciwieństwie do szkoły niemieckiej, która (...) bada prasę tylko jako zjawisko historyczne, socjologiczne, prawne czy ekonomiczne, [podejście amerykańskich prasoznawców - przyp. RF] obejmuje ona cały obiekt badań i wszystkie zachodzące w nim procesy, ze szczególnym uwzględnieniem warsztatu i jego mechaniki działania i oddziaływania ${ }^{6}$.

W znacznej mierze niezależnie od tego, jak mozolnie wyłaniała się świadomość potrzeby stworzenia nowej dyscypliny naukowej, zakotwiczonej instytucjonalnie na uniwersytetach i w specjalistycznych instytutach badawczych, przez całe XIX stulecie były prowadzone badania nad różnymi aspektami tego, co dopiero w przyszłości stać się miało zrębem prasoznawstwa. Te badania z umocowaniem akademickim uprawiane były przez historyków literatury, bibliografów czy bibliologów, a później także socjologów czy prawników, w ramach ich afiliacji akademickich. Zatem i o zawodowych uczonych, i o praktykach tworzących zręby instytucjonalnego prasoznawstwa będzie mowa w tym szkicu.

Okoliczności jego powstania związane są ze 100-leciem odzyskania niepodległości z perspektywy Krakowa. Stąd na wstępie musimy poczynić istotne zastrzeżenia. Po pierwsze, do momentu odrodzenia w 1918 roku nie było na ziemiach polskich (II Rzeczpospolita dopiero się krystalizowała) prasoznawstwa i prasoznawców jako takich. Stąd mówimy ostrożnie o badaniach nad prasą, prowadzonych pod różnymi szyldami. Po drugie zaś, koncentracja wyłącznie na Krakowie byłaby trudna do wykonania i szkodliwa; w owym czasie istotną rolę odgrywał ośrodek lwowski, stąd rozszerzenie spojrzenia na Galicję. Po trzecie, Kraków dla wielu badaczy i działaczy jest tylko przystankiem na drodze do rozwijania nowej dziedziny badań, choć potem tworzą i działają głównie w Warszawie czy innych regionach Polski. O nich także będzie tu mowa.

\section{Badania nad prasą w Krakowie i we Lwowie przed 1918 rokiem}

Badacze dziejów naszej dyscypliny wyróżniają przed I wojną światową trzy charakterystyczne okresy ${ }^{7}$, odpowiadające trzem stadiom wykrystalizowania się badań nad prasą (przypomnijmy oczywistość, że naówczas było to medium dominujące): (1) umownie nazwijmy to „romantycznym” (I połowa XIX wieku), (2) okres ,pozytywistyczny” (z grubsza II połowa XIX wieku) oraz (3) przełom wieków i początek wieku XX (przed I wojną światową).

W I połowie XIX wieku ${ }^{8}$ w badaniach dominuje nurt bibliograficzno-historyczny, uprawiany przez dwa pokolenia badaczy i to raczej niezwiązanych zawodowo z nauczaniem

\footnotetext{
${ }^{5}$ Ibidem, s. 37.

${ }^{6}$ Ibidem, s. 38. Ta uwaga jest jednak, jak się wydaje, bardziej adekwatna do okresu znacznie późniejszego, gdy już znana była tzw. formuła Lasswella, ujmująca całościowo najważniejsze elementy łańcucha komunikacyjnego.

${ }^{7}$ Zob. S. Dziki, Badania nad prasa, [w:] Encyklopedia wiedzy o prasie, Wrocław 1976, s. 27-28.

${ }^{8} \mathrm{~W}$ literaturze wskazuje się na pierwsze publikacje przypadające jeszcze na okres Oświecenia - a więc koniec wieku XVIII.
} 
akademickim. W pierwszym przypadku ich prace przypadają na czasy przed 1820 rokiem (A.T. Chłędowski i J.S. Bandtkie) ${ }^{9}$, następne zaś pokolenie reprezentuje K. Szajnocha, działający na przełomie lat 40. i 50. XIX w.

Adam Tomasz Chłędowski (1770-1855) studiował, a następnie działał we Lwowie ${ }^{10}$, gdzie był współzałożycielem „Pamiętnika Lwowskiego”. Z tamtym okresem jest związane dzieło O poczatkowych pismach periodycznych w języku polskim („Pamiętnik Lwowski” 1816). W tym samym czasie (1817) w Krakowie Jan Samuel Bandtkie (profesor bibliografii na UJ, kierownik Biblioteki Jagiellońskiej) wygłosił na posiedzeniu Towarzystwa Naukowego z Uniwersytetem Jagiellońskim połączonego odczyt pt. Wiadomość krótka o gazetach polskich, wydany drukiem w roku 1819 („Rocznik Towarzystwa Naukowego”). Bandtkie pierwszy „odkrył” istnienie „Merkuriusza Polskiego” i przeprowadził wszechstronną analizę pisma, choć wątpił, czy Jan Aleksander Gorczyn był rzeczywiście jego redaktorem ${ }^{11}$.

Karol Szajnocha (1818-1868) studiował od 1835 roku na Uniwersytecie Lwowskim ${ }^{12}$; w roku 1853 rozpoczął pracę jako zastępca kustosza w Bibliotece Ossolińskich, redagował też „Bibliotekę Naukową Zakładu im. Ossolińskich”. W tym periodyku opublikował w 1848 roku pracę Literatura czasowa w Polsce.

Jak podsumowuje Sylwester Dziki, oprócz rejestracji tytułów czasopism i ich bibliograficznych opisów, w pracach tych trafiają się już pierwsze próby ogólniejszych refleksji prasoznawczych (np. charakterystyka profilu politycznego pisma, omówienie jego treści i roli, prezentacje nowych metod badawczych) $)^{13}$.

U progu lat 60. XIX wieku zaczęła się krystalizować nowoczesna wiedza o prasie. Nastąpiło w tym czasie znaczne rozszerzenie zakresu badań - na organizację pracy dziennikarsko-wydawniczej, zawód dziennikarza i jego etykę. Z terenem Galicji związane są dwa ważne nazwiska ówczesnych badaczy: K. Estreichera oraz - w pewnej mierze S.J.N. Czarnowskiego.

Karol Józef Teofil Estreicher (1827-1908) był bibliotekarzem, bibliografem, historykiem literatury i historykiem prasy; w latach 1868-1905 - kierował Biblioteką Jagiellońską. Wcześniej (1862-1868) prowadził wykłady z bibliografii w warszawskiej Szkole Głównej, w nich zaś uwzględniał elementy wiedzy o prasie. Jeszcze w okresie warszawskim opublikował m.in. dwie prace historycznoprasowe dotyczące terenów Galicji: Ruch ksiażkowy $i$ dziennikarski $w$ Galicji $i$ innych prowincjach Polski przed 1849 (1859) oraz Dziennikarstwo w Galicji i w Krakowie do roku $1860(1861)^{14}$. Wiekopomne dzieło K. Estreichera to 26 tomów Bibliografii polskiej (wydawanych w okresie krakowskim, w latach 1870-1916). Estreicher, który podjął próbę syntezy historii prasy polskiej, uchodzi za pierwszego polskiego prasoznawcę. W swoich pracach brał pod uwagę zagadnienia

\footnotetext{
${ }^{9}$ Nurt ten zapoczątkował Feliks Bentkowski (1781-1852), działający w Wilnie (Historia literatury polskiej, t. 1, Wilno 1814, s. 125-133), a potem w Warszawie.

${ }^{10}$ Od 1919 roku pracował w Warszawie jako bibliotekarz w Bibliotece Publicznej.

${ }^{11}$ Zob. M. Kafel, op. cit., s. 42.

${ }^{12}$ Usunięty ze studiów za działalność polityczną i więziony. Był samoukiem.

${ }^{13}$ S. Dziki, op. cit., s. 27. Pod koniec I połowy XIX wieku pojawiły się też próby budowania ogólnej teorii dziennikarstwa (m.in. pisarz J.I. Kraszewski), ale działo się to poza terenem Galicji.

${ }^{14}$ Zob. Ruch ksiqżkowy $i$ dziennikarski $w$ Galicji $i$ w innych prowincjach Polski przed 1849, ,Dodatek tygodniowy przy Gazecie Lwowskiej” 1859; Dziennikarstwo w Galicji i w Krakowie do roku 1860, „Biblioteka Warszawska" 1861.
} 
finansowe prasy i rozwijał badania statystyczne prasy. Miał istotny dorobek w zakresie bibliografii, statystyki i historii prasy ${ }^{15}$.

Stanisław Jan Nepomucen Czarnowski (1847-1929) jest bardziej pamiętany jako archeolog amator ${ }^{16}$, ale dał się także poznać jako globtroter, historyk prasy i literatury, dziennikarz i wydawca, związany początkowo głównie z Warszawą ${ }^{17}$, a po I wojnie światowej - z Kielcami. Jako prekursor nowoczesnych badań prasoznawczych zasłynął dwoma pracami: Postępy literatury periodycznej (Warszawa 1886), a zwłaszcza późniejszą, dwutomowa, wydaną w Krakowie: Literatura periodyczna i jej rozwój (tom I - 1892, tom II - 1895). W 1895 roku w Krakowie wydał także Dziennikarstwo słowiańskie i polskie. Główne dzieło Czarnowskiego (Literatura periodyczna...), oparte na bogatych materiałach zgromadzonych na zorganizowaną przez niego międzynarodową wystawę prasy w Nicei (1884-1885) oraz na wynikach badań innych autorów światowych, uchodziło za nowatorskie; ,stanowi pierwszą próbę nie tylko w piśmiennictwie polskim encyklopedycznego opracowania całokształtu dziejów dziennikarstwa światowego, ukazania roli oraz mechanizmu działania prasy w społeczeństwach" ${ }^{18}$. Będąc też wydawcą praktykiem, podejmował takie zagadnienia warsztatowe, jak organizacja pracy redakcji, technika prasy, ekonomika wydawnicza, zawód (,stan”) dziennikarski, gatunki dziennikarskie, ustawodawstwo prasowe. W analizach rynku prasowego i porównaniach międzynarodowych stosował ciekawe rozwiązania statystyczne (np. miarą rozwoju czytelnictwa był wskaźnik: „stosunek numerów na jednego mieszkańca rocznie") ${ }^{19}$.

W drugiej połowie XIX w. w zaborze austriackim ukazało się kilka prac o języku prasy, podnoszących kwestię kultury języka ojczystego i niebezpieczeństwa braku dbałości o jego czystość, jak choćby barbaryzmy i inne niekorzystne zjawiska utrwalane przez tamtejszą prasę (zwłaszcza seria prac Fryderyka Skobla O skażeniu języka polskiego w dziennikach..., z lat 1870-1877) ${ }^{20}$.

\section{Idee promieniujące z Galicji}

Na przełomie wieków i w latach poprzedzających I wojnę światową można dostrzec zarówno dążność do pogłębionych syntez historycznoprasowych, jak i prac specjalistycznych w wielu kierunkach (prasa lokalna, specjalistyczna, monografie poszczególnych tytułów, wolność prasy i prawo prasowe etc.). Twórcy zrębów prasoznawstwa w tych latach działali potem także aktywnie w niepodległej Polsce.

${ }^{15}$ Zob. S. Dziki, op. cit., s. 27.

${ }^{16}$ Po powrocie z podróży po krajach zachodnich osiadł Czarnowski na kilkanaście lat w Ojcowie. Prace wykopaliskowe prowadził własnym sumptem (poświęcając majątek) od 1895 r. w okolicach Krakowa (Dolina Prądnika), stworzył muzea regionalne w Ojcowie i Miechowie (choć to były w tym czasie tereny Kongresówki).

${ }^{17}$ W Warszawie wydawał Czarnowski „Warszawski Rocznik Literacki” (1871-1880) oraz „Tygodnik Przemysłowo-Handlowy" (1872-1873).

${ }^{18}$ S. Dziki, Stanisław J. Czarnowski [1847-1929] - prekursor badań prasoznawczych, Sprawozdania Komisji Naukowych PAN. Oddział w Krakowie, 1979, t. 23, cz. 1, s. 91.

${ }^{19}$ Zob. M. Kafel, op. cit., s. 47-48.

${ }^{20}$ Zob. W. Pisarek, Pierwsze polskie ksiażki o języku prasy, „Zeszyty Prasoznawcze” 1963, nr 4, s. 75-84. 
Prężny był w owym czasie ośrodek lwowski. Profesorami tamtejszego uniwersytetu byli na początku XX wieku Wilhelm Bruchnalski (1859-1938) i Szymon Askenazy (1866 lub 1867-1935). Pierwszy z nich, historyk literatury polskiej, znany jest z opracowania monografii „Gazety Lwowskiej”, drugi zaś, historyk stosunków międzynarodowych i dyplomata, zasłynął prowadzeniem seminarium (na Uniwersytecie Jana Kazimierza), które zaowocowało powstaniem kilku ważnych prac z zakresu prasoznawstwa. Najbardziej znanym jego seminarzystą (od 1903 r.) był Stefan Gorski (1882-1941), związany po studiach (jako dziennikarz i wydawca) głównie z Łodzią, Płockiem i Warszawą. Gorski był inicjatorem organizacji kursów dziennikarskich; utworzył w 1904 roku Kółko Dziennikarskie przy Czytelni Akademickiej i przetłumaczył w ramach seminarium Askenazego pierwszy podręcznik dziennikarstwa Emila Löbla: Kultura i prasa (wydany w 1905 roku w Warszawie). S. Gorski napisał także syntetyczną pracę Dziennikarstwo polskie (Warszawa 1905), a ponadto dzieło podejmujące zagadnienie wolności prasy ( $Z$ dziejów cenzury w Polsce, Warszawa 1906). Na seminarium Askenazego zrodziła się myśl o potrzebie utworzenia ośrodka badań nad prasą jako zalążka przyszłego instytutu prasoznawczego i studiów dziennikarskich ${ }^{21}$. Ten pomysł zyskał wkrótce podatny grunt w prasie polskiej.

Wspomniana idea kiełkowała jednak od jakiegoś czasu w kręgach stowarzyszeń dziennikarskich, wraz z dyskusjami o (nieistniejącym przecież na ziemiach polskich) szkolnictwie dziennikarskim. Już w roku 1881 powstało w Galicji Koło Literacko-Artystyczne (skupiało pisarzy, dziennikarzy i aktorów) ${ }^{22}$; w 1893 roku we Lwowie założono pierwsze na terenie kraju Towarzystwo Wzajemnej Pomocy Dziennikarzy Polskich, przekształcone w 1895 roku w Towarzystwo Dziennikarzy Polskich (w roku następnym przystąpiło ono do Międzynarodowego Związku Prasy) ${ }^{23}$. Już w 1894 roku we Lwowie na II Zjeździe Literatów i Dziennikarzy ${ }^{24}$ dyskutowano potrzebę badań nad prasą. Kwestie te odżyły jeszcze mocniej w 1911 roku na krajowym zjeździe dziennikarzy w Krakowie z okazji 250. rocznicy ukazania się „Merkuriusza Polskiego”. Inicjatorem organizacji tego zjazdu i wielkim entuzjastą wcześniejszych pomysłów S. Gorskiego był Stanisław Jarkowski, który właściwie całe późniejsze życie poświęcił na mozolne próby ich realizacji. Ponieważ to postać nietuzinkowa, należy mu poświęcić nieco więcej miejsca.

Stanisław Teofil Jarkowski (1882-1947) podjął studia prawnicze na Uniwersytecie Warszawskim, ale na II roku wyjechał do Lipska, gdzie studiował nauki ekonomiczne w Wyższej Szkole Handlowej (1905-1906), a potem (w latach 1907-1911 z dwoma przerwami) nauki społeczne na tamtejszym uniwersytecie, w tym odbył studia prasoznawcze u prof. Karla Büchera (jednego z pionierów wiedzy o prasie), odwiedzając w międzyczasie także uniwersytety w Wiedniu i Szwajcarii; spędził też rok w Paryżu, zajmując się badaniem prasy i stosunków prasowych. Już w czasie studiów opublikował (w czasopismach wie-

${ }^{21}$ Zob. S. Dziki, Z dziejów polskiego czasopiśmiennictwa prasoznawczego, ,Zeszyty Prasoznawcze” 1988, nr 2, s. 5; Idem, U narodzin polskiego szkolnictwa dziennikarskiego, „Zeszyty Prasoznawcze” 2010, nr 3-4, s. 168 .

${ }^{22}$ Oddzielenie dziennikarzy od literatów dokonało się u nas dopiero po 1918 roku. Zob. Cz. Lechicki, Najstarsze organizacje dziennikarskie, „Zeszyty Prasoznawcze” 1967, nr 2, s. 87.

${ }^{23}$ Zob. M. Kafel, op. cit., s. 50.

${ }^{24}$ Pierwszy zjazd dziennikarzy (z udziałem zaledwie 17 osób, bez reprezentantów zaboru rosyjskiego i emigracji) miał miejsce w Krakowie ćwierć wieku wcześniej (15 IX 1868), choć nie przyniósł on żadnych wymiernych postanowień. Zob. Cz. Lechicki, Pierwszy zjazd dziennikarzy polskich w Krakowie 1868 r., „Prasa Współczesna i Dawna” 1958, nr 2, s. 141-143. 
deńskich i paryskich) kilka większych prac z dziedziny historycznoprasowej, wygłosił kilkanaście referatów ekonomicznych, jak również napisał dysertację doktorską o polskiej prasie obcojęzycznej (Die polnische deutschsprachliche Presse) ${ }^{25}$. Po studiach w 1911 roku wrócił do Warszawy i opublikował przeszło 100-stronicową pracę pt. Literatura dotyczqca prasy polskiej (Notatki krytyczno-bibliograficzne) (Warszawa 1911). To pierwsze tak poważne opracowanie w tej dziedzinie, przygotowane na 250-lecie istnienia prasy polskiej, miało być wstępem do projektowanego dzieła zbiorowego o prasie polskiej. Jarkowski wzywał w nim do utworzenia archiwum przyczynków i dokumentów do dziejów prasy polskiej. Od 1912 roku pracował w zawodzie dziennikarza, równocześnie zbliżając się do problematyki księgarsko-wydawniczejej6.

Do końca życia, przez blisko cztery następne dekady (przedzielone dwiema wojnami światowymi) Jarkowski walczył o spełnienie trzech głównych punktów swego planu: uruchomienie ośrodka badań nad prasą, edycję odpowiedniego czasopisma branżowego oraz uruchomienie szkolnictwa dziennikarskiego. Tak więc idee wykute w Krakowie wcielano w życie, już po odrodzeniu Rzeczpospolitej, głównie w Warszawie.

\section{Zabiegi o szkolnictwo dziennikarskie}

Stosunkowo najłatwiej i najszybciej udało się zrealizować punkt dotyczący kształcenia dziennikarzy. Po kilku nieudanych próbach wystartowała w Krakowie w latach 1911-1914, z inicjatywy Michała Jana Rostworowskiego, Polska Szkoła Nauk Politycznych (dwuletnie studium); choć była to szkoła prywatna, funkcjonowała w ścisłej łączności z UJ i skupiała wielu wykładowców z uniwersytetu i innych ośrodków (wśród nich posła do Dumy - Romana Dmowskiego). Szkoła zaprzestała działalności po wybuchu I wojny światowej, niemniej zdążyła wypuścić dwa roczniki absolwentów, a jednym z nich był Melchior Wańkowicz ${ }^{27}$.

Jeszcze podczas I wojny, od 1916 roku w ramach działalności Towarzystwa Literatów i Dziennikarzy Polskich brał S. Jarkowski czynny udział w naradach w sprawie organizacji szkolnictwa dziennikarskiego w Polsce, zaś w 1917 roku współorganizował (wraz z Wincentym Trzebińskim, a potem i Józefem Wasowskim) dwie powstające równocześnie warszawskie uczelnie dziennikarskie: (1) Wydział Dziennikarsko-Publicystyczny przy Szkole Nauk Społecznych (od 1918 - Szkoła Nauk Politycznych z siedzibą przy ul. Reja 7) oraz (2) Szkołę Dziennikarsko-Publicystyczną przy Wolnej Wszechnicy Polskiej [w 1927 roku została przemianowana na Wyższą Szkołę Dziennikarską (WSD); od 1936 roku w nowej siedzibie przy ul. Rozbrat 44a]. Co ciekawe, S. Jarkowski wykładał na obydwu tych uczelniach do wybuchu II wojny światowej. Po wojnie, w październiku 1947 roku z inicjatywy Związku Zawodowego Dziennikarzy, wznowiono działalność

\footnotetext{
${ }^{25}$ Zob. M. Czajkowska, Stanisław Teofil Jarkowski. Bibliografia prac S. Jarkowskiego w układzie chronologicznym, „Prasa Współczesna i Dawna”, 1958, nr 4, s. 113-121. Nie znajduję nigdzie potwierdzenia, że dysertacja doktorska została obroniona.

${ }^{26}$ Więcej informacji o życiu i działalności S. Jarkowskiego znajdujemy w dwóch pracach Marii Czajkowskiej: Stanisław Teofil Jarkowski... oraz Wspomnienia o Stanisławie Jarkowskim, profesorze Wyższej Szkoły Dziennikarskiej w Warszawie, ,Zeszyty Prasoznawcze” 1968 nr 3, s. 74-80.

${ }^{27}$ Więcej pisze o tym S. Dziki, U narodzin polskiego szkolnictwa dziennikarskiego, s. 170.
} 
WSD (dyrektorem został W. Trzebiński, a wśród wykładowców znalazł się J. Wasowski; nie dożył już tego S. Jarkowski) ${ }^{28}$. Przed śmiercią Jarkowski zdołał przygotować konspekt wykładów o prasoznawstwie na potrzeby kursów planowanych w Związku Bibliotekarzy.

\section{Batalia o periodyk o prasie}

Ważnym rezultatem wspomnianego Krakowskiego Zjazdu Dziennikarzy (1911) był projekt pisma branżowego pt. „Archiwum Prasy Polskiej”, przedstawiony przez S. Jarkowskiego. Autor pomysłu nie przesądzał częstotliwości jego ukazywania się - miał to być miesięcznik lub kwartalnik, półrocznik, a nawet tylko rocznik. Przewidywany układ treści „Archiwum Prasy Polskiej” obejmował:

- szczegółowy dział bibliograficzny,

- większe artykuły, omawiające różne zagadnienia ważne dla całego zawodu dziennikarskiego,

- większe lub mniejsze studia i rozprawy dotyczące dziejów prasy polskiej,

- kronikę bieżącą ruchu wydawniczo-prasowego,

- kronikę zagranicznej prasy,

- różne inne działy oraz rubryki specjalne ${ }^{29}$.

Pomysł ten (w 1914 roku przymierzano się do wydawania „Rocznika Prasy Polskiej”, były już gromadzone teksty, ale brakło środków i wybuchła wojna) doczekał się realizacji dopiero wiele lat później (1947), choć w okresie międzywojennym pojawiały się pisma akademickie (np. „Młoda Prasa” 1918-1919) 30, a zwłaszcza wydawano pisma branżowe, firmowane przez różne stowarzyszenia wydawców (warszawski dwumiesięcznik, a od 1931 roku miesięcznik „Prasa” - 1930-1939; poznański „Przegląd Wydawniczy”, „Przegląd Graficzny i Papierniczy”, „Przegląd Graficzny, Wydawniczy i Papierniczy”- tytuł ten ewoluował i in.). Planom Jarkowskiego w tym zakresie przeszkodził wybuch II wojny światowej. Idea odżyła w 1947 roku, gdy w czerwcu zadebiutował miesięcznik „Prasa Polska", którego koncepcję stworzył i pierwszy numer redagował S. Jarkowski ${ }^{31}$. Współwydawcami pisma były stworzony przez Jarkowskiego Polski Instytut Prasoznawczy (PIP), oraz Związek Zawodowy Dziennikarzy RP, a także Polski Związek Wydawnictw Praso$\mathrm{wych}^{32}$.

${ }^{28}$ Już w 1948 r. WSD przekształciła się w Wydział Dziennikarski Akademii Nauk Politycznych, który w tym samym roku został zlikwidowany. Natomiast powołano 3-letnie Studium Dziennikarskie przy Wydziale Społeczno-Politycznym ANP. W tamtym czasie powstały podobne studia w Krakowie i Łodzi, a także kursy organizowane przez organizacje związkowe. Zob. M. Kafel, op. cit., s. 70-72.

${ }^{29}$ Zob. S. Dziki, Z dziejów polskiego czasopiśmiennictwa prasoznawczego, s. 6.

${ }^{30}$ Pismo wydawane przez studentów Szkoły Dziennikarstwa i Publicystyki przy Wolnej Wszechnicy Polskiej w Warszawie; kuratorem stowarzyszenia był S. Jarkowski.

${ }^{31}$ S. Jarkowski zmarł 11 czerwca 1947 roku, nie doczekawszy debiutu swego miesięcznika.

${ }^{32}$ Po likwidacji PIP w czasach stalinowskich od nru 1/2/1950 r. „Prasa Polska” była miesięcznikiem Związku Zawodowego Dziennikarzy RP i Polskiego Związku Wydawnictw Prasowych, a od nru 3/1951 r. stała się organem Stowarzyszenia Dziennikarzy Polskich (długoletni red. Florian Dłużak). „Prasa Polska” ukazywała się do 1991 roku. 
„Prasa Polska” była pismem branżowym, środowiskowym, skierowanym głównie do dziennikarzy, jakkolwiek niepozbawionym tekstów pisanych przez ludzi z kręgów naukowych. Ambicje periodyku naukowego miały dopiero kwartalniki debiutujące dekadę później, w okresie popaździernikowym - „Kwartalnik Prasoznawczy” (1957-1959, redagowany przez Mieczysława Kafla w Zakładzie Badań Prasoznawczych w Warszawie) oraz związana z (Krakowskim) Ośrodkiem Badań Prasoznawczych „Prasa Współczesna i Dawna” (1958-1959), przekształcona niebawem w „Zeszyty Prasoznawcze” (od roku 1960 do dziś).

\section{Walka o ośrodek badań nad prasą}

Trzecia idea zjazdu krakowskiego, tzn. organizacja placówki badawczej wyspecjalizowanej w badaniach nad prasą, także materializowała się przez kilka dziesięcioleci, a swój finał znalazła dopiero po II wojnie światowej. Bezpośrednio po odzyskaniu niepodległości w 1918 roku nie było warunków do stworzenia takiej placówki o ambicjach naukowych, tym bardziej że nie było także, jak pamiętamy, zaplecza w postaci szkolnictwa dziennikarskiego. W 1919 roku udało się Jarkowskiemu jedynie uruchomić komercyjne biuro wycinków Informacja Prasowa Polska (IPP). Natomiast z powodów finansowych spełzł na niczym projekt pt. Gazeta Gazet; miał to być codzienny serwis prasowy zawierający streszczenia ukazujących się artykułów i wiadomości, a z prasy zagranicznej - artykuły i wzmianki o sprawach polskich. Po kilku latach (1924/1925) powiodło się uruchomienie stałej publikacji - Informacji Powszechnej, z działami: przegląd tygodniowy życia społecznego i kulturalnego, sztuka i krytyka oraz gazeta gazet. Ambicją Jarkowskiego było uczynienie z IPP ośrodka wiedzy o prasie. Założył archiwum, które gromadziło ukazujące się w prasie wzmianki i artykuły mogące służyć do studiów prasoznawczych. Zainicjował także (pod swą redakcją) serię wydawniczą pt. Biblioteka Prasowa Polska, która w latach 1921-1928 była wydawana pod auspicjami IPP, a w 1929 roku została przejęta przez Wyższą Szkołę Dziennikarską (WSD); w latach 1921-1939 ukazało się łącznie 12 tomików tej serii, w tym - 7 autorstwa samego Jarkowskiego. Te prace zostały po latach ocenione jako „(...) artykuły, a w najlepszym razie broszury nie różniące się poziomem od artykułów"33.

Przez długi czas sprawa utworzenia placówki badawczej znajdowała zrozumienie głównie w kręgach zawodowych dziennikarzy i literatów, ale większej realności nabrała dopiero po powstaniu w 1928 roku Polskiego Związku Wydawców Dzienników i Czasopism (PZWDiC), za sprawą wspomnianych już S. Jarkowskiego, W. Trzebińskiego i J. Wasowskiego $^{34}$. W przyszłym Instytucie Prasoznawczym widziano zarówno ośrodek badający warunki pracy dziennikarskiej, jak i swego rodzaju laboratorium pokazowe dla studentów Wyższej Szkoły Dziennikarskiej. Ta ostatnia, obok kształcenia nowych kadr dziennikarskich, stawiała sobie za cel główny pracę badawczą. Ale dopiero w 1936 roku idea znalazła wsparcie nie tylko związkowców z PZWDiC, ale i rektora Uniwersytetu Warszawskiego.

\footnotetext{
${ }^{33}$ Zob. R. Marylska, Pierwsze próby organizacji badań prasoznawczych w okresie 1918-1939, „Kwartalnik Prasoznawczy" 1958, nr 1-2, s. 109.

${ }^{34}$ Wcześniej wymienieni tu Jarkowski, Trzebiński i Wasowski organizowali wiele wystaw prasy krajowej, prowincjonalnej, także zagranicznej, wydawali katalogi i opisy bibliograficzne.
} 
Krokiem ku temu było powołanie w 1938 roku Towarzystwa Wiedzy o Prasie. Dopiero na jego bazie miał powstać w 1939 roku Instytut Wiedzy Prasowej; głównymi jego organizatorami byli ówcześni profesorowie WSD - S. Jarkowski, W. Trzebiński i J. Wasowski ${ }^{35}$. I znowu wybuch wojny uniemożliwił finalizację planów. Po wojnie, w latach 1946-1947 S. Jarkowski zorganizował Polski Instytut Prasoznawczy (PIP), powołany przez Wydział Wykonawczy Związku Zawodowego Dziennikarzy RP w Warszawie. W dniu 15 lutego 1947 wygłosił obszerny referat za zebraniu organizacyjnym PIP pt. O prasie, wiedzy o niej, nauczaniu dziennikarskim oraz o literaturze prasoznawczej, a także potrzebach P.I.P. Jarkowski zabiegał o reaktywację biura wycinków (ale brakło środków). Instytut nie zdołał rozwinąć szerszej działalności zarówno w związku ze śmiercią Jarkowskiego, jak i postępującą stalinizacją kraju. W 1950 roku został zlikwidowany.

Dopiero w pół wieku po krakowskim zjeździe dziennikarzy idea stworzenia ośrodka badań nad prasą zmaterializowała się w pełni na gruncie koncernu RSW „Prasa”. Najpierw w 1954 roku utworzono Zakład Badań Prasoznawczych w Warszawie ${ }^{36}$, zaś w połowie 1956 roku - Krakowski Ośrodek Badań Prasoznawczych (KOBP). Pierwszy, koncentrujący się głównie na badaniach historycznoprasowych, został zlikwidowany w 1959 roku; drugi natomiast przekształcono w 1960 roku w ogólnokrajowy Ośrodek Badań Prasoznawczych z siedzibą w Krakowie; działał on pod szyldem RSW do 1990 roku $^{37}$, prowadząc (pod kierownictwem Ireny Tetelowskiej, a po jej śmierci w 1969 roku - Walerego Pisarka) szerokie spektrum badań interdyscyplinarnych, zorganizowanych według głównych ogniw łańcucha komunikacyjnego (studia nad nadawcą, przekazem, odbiorca), z rozbudowanym działem dokumentacji prasowej. Do OBP trafiły też zbiory biblioteki prasoznawczej PIP, tzn. ta część, która przetrwała wojnę w warszawskim mieszkaniu Stanisława Jarkowskiego. To jeszcze jeden przykład, jak bardzo historia zatoczyła koło od czasów przywoływanego tu krakowskiego epizodu z 1911 roku.

\section{Uwagi końcowe}

Dokonany tu przegląd ważniejszych osiągnięć na polu badawczym i organizatorskim ludzi, których można potraktować jako pionierów polskiej myśli prasoznawczej, ma charakter subiektywny, a przede wszystkim nieco sztuczny. Albowiem nieco na siłę przypisano poszczególnym zasłużonym postaciom związki z Krakowem, a gdy takich nie dało się ustalić - ze Lwowem i szerzej - z terenem Galicji, zaboru austriackiego. Ale to tutaj, w sytuacji względnej autonomii mogły śmielej kiełkować pewne idee i być podejmowane działania organizatorskie, które, nie bez trudu i zwykle nie natychmiast, przybierały materialną postać w warunkach odrodzonej Rzeczypospolitej. Rzecz znamienna, w życiu niektórych wielkich postaci, związanych z Warszawą, można rzec - ojców polskiego pra-

\footnotetext{
${ }^{35}$ Zob. M. Kafel, op. cit., s. 62-63.

${ }^{36}$ Pracownicy ZBP stanowili trzon odbudowywanych w latach 60. XX w. studiów dziennikarskich na Uniwersytecie Warszawskim.

${ }^{37}$ Od 1 X 1990, w następstwie likwidacji koncernu RSW „Prasa-Książka-Ruch”, OBP został przejęty przez Uniwersytet Jagielloński; tam jeszcze do końca lat 90. pod kierownictwem prof. W. Pisarka działał jako placówka naukowo-badawcza. Po zmianach organizacyjnych 1998/1999 pracownicy katedry OBP podjęli głównie obowiązki dydaktyczne w strukturze Instytutu Dziennikarstwa i Komunikacji Społecznej na WZiKS.
} 
soznawstwa, Kraków odegrał rolę epizodyczną, ale nietuzinkową. Tu pod koniec XIX wieku ukazało się pionierskie dzieło S. Czarnowskiego, tu kilka lat przed wybuchem I wojny światowej konkretyzowała się rzucona parę lat wcześniej we Lwowie idea stworzenia nie tylko wyspecjalizowanej placówki badawczej i organu prasowego publikującego m.in. prace badawcze z dziedziny studiów nad prasą, ale także budowy szkolnictwa dziennikarskiego. Projekty te, jak widzieliśmy, materializowały się stopniowo, mozolnie ${ }^{38}$, a prasoznawstwo jako nowa dyscyplina naukowa znalazło instytucjonalną osłonę dopiero pół wieku po rzuceniu tego hasła, u progu lat 60. XX wieku.

W pierwszych pokoleniach badaczy prasy znajdujemy stosunkowo niewielu uczonych akademickich zajmujących się prasą w ramach swoich dyscyplin naukowych (zwłaszcza historii literatury, bibliografów, prawników); częściej byli to praktycy - dziennikarze, wydawcy książek czy gazet, podejmujący badania niejako hobbistycznie. W II RP świadomość takiej potrzeby emancypacji rosła wraz z umacnianiem się szkolnictwa dziennikarskiego, w czym szczególną rolę odegrała warszawska WSD. Należy zgodzić się z konstatacją A. Garlickiej sprzed półwiecza, gdy pisała: „Podstawy nowoczesnych badań nad prasą kształtowały się (...) wraz z powstawaniem nowoczesnego dziennikarstwa" ${ }^{39}$. Nie zmienia to faktu, że przez wiele dekad prasoznawstwo krzepło w oparciu o działania praktyków - związków branżowych, związków dziennikarskich, a wreszcie, w PRL - koncernu RSW, a nie uczelni akademickich.

\section{Bibliografia}

Czajkowska M., Stanisław Teofil Jarkowski. Bibliografia prac S. Jarkowskiego w układzie chronologicznym, „Prasa Współczesna i Dawna” 1958, nr 4, s. 113-121.

Czajkowska M., Wspomnienia o Stanisławie Jarkowskim, profesorze Wyższej Szkoły Dziennikarskiej $w$ Warszawie, ,Zeszyty Prasoznawcze” 1968, nr 3, s. 74-80.

Dubiel P., Goban-Klas T., Pisarek W., Prasoznawstwo polskie - tradycje, dorobek, perspektywy, „Zeszyty Prasoznawcze” 1974, nr 3, s. 5-16.

Dziki S., Stanisław J. Czarnowski [1847-1929] - prekursor badań prasoznawczych, Sprawozdania Komisji Naukowych PAN. Oddział w Krakowie 1979, T. 23 [cz.] 1 [druk.:] 1981, s. 91.

Dziki S., Badania nad prasq w Polsce. Hasło w: Encyklopedia wiedzy o prasie (pod red. Juliana Maślanki), Wrocław-Warszawa-Kraków-Gdańsk 1976, s. 27-31.

\footnotetext{
${ }^{38}$ Wymowna jest polemika rozgorzała w 1932 roku pomiędzy Stanisławem Jarkowskim a Władysławem Wolertem (docentem dziennikarstwa na WWP w Warszawie) na temat zasadności tworzenia Instytutu Prasoznawczego; Wolert był zdecydowanie przeciw (jako postulat przedwczesny). Zob. R. Marylska, op. cit., s. 110. Przypomnijmy, że Wolert jest autorem fundamentalnego dzieła Szkice z dziejów prasy światowej, Kraków 2005, opracowanego redakcyjnie i pod zmienionym tytułem (pierwotny: Porównawcza historia prasy światowej) dopiero wiele lat po śmierci autora przez Sylwestra Dzikiego i opatrzonego wstępem Mariana Tyrowicza. W. Wolert (1890-1946) po wojnie osiadł w Krakowie jako wykładowca Studium Pedagogicznego UJ. O wspomnianej polemice zob. także: M. Czajkowska, Wspomnienie o Stanisławie Jarkowskim profesorze Wyższej Szkoty Dziennikarskiej w Warszawie, „Zeszyty Prasoznawcze” 1968, nr 3, s.77. Obszerny szkic o dziele W. Wolerta i inspiracjach zaczerpniętych z prac S. Czarnowskiego napisał Marian Tyrowicz, Władysław Wolert i jego poglady na dzieje prasy, „Kwartalnik Historii Prasy Polskiej” 1980, R. XIX, z. 1, s. 5-18.

${ }^{39}$ A. Garlicka, Rozwój badań nad historia prasy polskiej, „,Rocznik Historii Czasopiśmiennictwa Polskiego” 1962, t. I, s. 21.
} 
Dziki S., Z dziejów polskiego czasopiśmiennictwa prasoznawczego, „Zeszyty Prasoznawcze” 1988, nr 2, s. 5-16.

Dziki S., U narodzin polskiego szkolnictwa dziennikarskiego, „Zeszyty Prasoznawcze” 2010, nr 3-4, s. 161-173.

Filas R., Płaneta P., Zeszyty Prasoznawcze (1958-2013). An outline of the structure, content and social features of the quarterly, „Central European Journal of Communication”, Volume 7, No 1 (12), Spring 2014, s. 119-135.

Garlicka A., Rozwój badań nad historia prasy polskiej, „Rocznik Historii Czasopiśmiennictwa Polskiego" 1962, t. I, s. 7-48.

Kafel M., Z historii badań nad prasq w Polsce, „Zeszyty Prasoznawcze” 1963, nr 1-2, s. 3-24.

Kafel M., Szkoty dziennikarskie i ośrodki badań nad prasq, „Zeszyty Prasoznawcze” 1964, nr 3, s. $153-175$.

Kafel M., Prasoznawstwo. Wstęp do problematyki, PWN, Warszawa 1966

Lechicki C., Pierwszy zjazd dziennikarzy polskich w Krakowie 1868 r., „Prasa Współczesna i Dawna” 1958, nr 2, s. 141-143.

Lechicki C., Najstarsze organizacje dziennikarskie, „Zeszyty Prasoznawcze” 1967, nr 2, s. 86-93.

Marylska R., Pierwsze próby organizacji badań prasoznawczych w okresie 1918-1939, „Kwartalnik Prasoznawczy" 1958, nr 1-2, s. 108-112.

Pisarek W., Polish media studies between past and future. The role of the Press Research Centre $(O B P)$ in Cracow, „Central European Journal of Communication”, Volume 7, No 1 (12), Spring 2014, s. 136-150.

Pisarek W., Pierwsze polskie ksiqżki o języku prasy, „Zeszyty Prasoznawcze” 1963, nr 4, s. 75-84.

Tyrowicz M., Władysław Wolert i jego poglady na dzieje prasy, „Kwartalnik Historii Prasy Polskiej” 1980, R. XIX, z. 1, s. 5-18.

Ryszard Filas, dr hab., pracownik Instytutu Dziennikarstwa, Mediów i Komunikacji Społecznej Uniwersytetu Jagiellońskiego (30-348 Kraków, ul. Łojasiewicza 4).

ryszard.filas@uj.edu.pl

ORCID: 0000-0002-9914-851X 